\title{
Mechanical Properties of a Water Hyacinth Nanofiber Cellulose Reinforced Thermoplastic Starch Bionanocomposite: Effect of Ultrasonic Vibration during Processing
}

\author{
Mochamad Asrofi ${ }^{1}$ (D), Hairul Abral ${ }^{1, *}$, Anwar Kasim ${ }^{2}$, Adjar Pratoto ${ }^{1}$, Melbi Mahardika ${ }^{1}$ (D) \\ and Fadli Hafizulhaq ${ }^{1}$ \\ 1 Department of Mechanical Engineering, Andalas University, 25163 Padang, Sumatera Barat, Indonesia; \\ asrofi.net@gmail.com (M.A.); adjar.pratoto@ft.unand.ac.id (A.P.); melbimahardika@gmail.com (M.M.); \\ hafizulhaq.fadli@gmail.com (F.H.) \\ 2 Department of Agriculture Technology, Andalas University, 25163 Padang, Sumatera Barat, Indonesia; \\ anwar_ks@yahoo.com \\ * Correspondence: abral@ft.unand.ac.id; Tel.: +62-812-672-0355
}

Received: 12 March 2018; Accepted: 5 June 2018; Published: 8 June 2018

\begin{abstract}
Thermoplastic starch (TPS) reinforced by $1 \mathrm{wt} \%$ nanofiber cellulose (NFC) reinforcing from water hyacinth was produced. Ultrasonic vibration time (UVT) was applied to bionanocomposites during gelation for $0,15,30$ and $60 \mathrm{~min}$. Morphology of the NFC was investigated using Transmission Electron Microscopy (TEM). Scanning Electron Microscopy (SEM) and tensile tests were performed to identify the fracture surface and determine the mechanical properties of the bionanocomposites, respectively. The Crystallinity index (CI) of untreated and treated bionanocomposites was measured using X-ray Diffraction (XRD). The average diameter of NFC water hyacinth was 10-20 nm. The maximum tensile strength (TS) and modulus elasticity (ME) of the bionanocomposite was 11.4 MPa and $443 \mathrm{MPa}$ respectively, after 60 min UVT. This result was supported by SEM which indicated good dispersion and compact structure.
\end{abstract}

Keywords: nanofiber cellulose; water hyacinth; thermoplastic starch; bionanocomposites; ultrasonic vibration time

\section{Introduction}

Reducing the use of synthetic plastics has become a special focus for researchers due to the environmental problems caused by non-biodegradable plastic waste. Recent innovations have included mixing synthetic with bio-based material (hybrid) and using fully biodegradable materials (bioplastics). The development of bioplastics to replace synthetic plastics has gained prominence in the last 10 years [1,2]. Bioplastics can be made from starch using shear stress and heat treatment at $60-70{ }^{\circ} \mathrm{C}[3,4]$ and they can be low cost and environmental friendly $[5,6]$. However, these plastics have various disadvantages including lower mechanical strength, water resistance, and thermal properties than synthetic plastics $[7,8]$. These disadvantages can be reduced by addition of natural fiber as a reinforcing agent into the starch matrix. The natural fibers commonly used are microfibers, with a diameter in micron meter area $(1-1000 \mu \mathrm{m})$, or nanofibers with a diameter of 1-100 nanometers $[9,10]$. Microfibers sourced from kenaf [4], water hyacinth [5,11], ramie [12,13], empty palm oil bunches (TKKS) [6], and microalgae [14] and chitin [15] have been used in previous studies. However, these microfibers usually form agglomerations and porosities when dispersed in a starch matrix and resulting in low mechanical properties [6]. 
To reduce the agglomeration, fiber must be made nano-sized. Smaller fibers result in better biocomposites due to high contact surface area, lower density, and good mechanical properties $[9,16]$. However, even nanofiber may not distribute homogeneously throughout the starch matrix. This may result in the reduction of the mechanical properties of the biocomposite [17]. Furthermore, nanofiber is expensive to produce and processing often results in low nanofiber yield. This is a problem as generally higher loading values of fiber are necessary for significant improvements in properties of the resulting biocomposite material [18].

Ultrasound treatment after gelation has been recommended to overcome this as it uniformly distributes the fiber throughout the matrix as the kinetic energy is released by ultrasound, which breaks down the fiber agglomerations into individual fibers scattered throughout the matrix $[6,19]$. This has been reported to result in more compact structures, improved mechanical properties, water resistance, and good film formation [5,6,20].

Water hyacinth is one possible source of natural fiber which is low cost, non-toxic, and abundant in Indonesia. It has approximately $40 \%$ cellulose content which is comparable with the fiber content from other sources [21]. Cellulose content has an important influence on the properties of biocomposites. The higher cellulose content leads to better mechanical and thermal properties as reported in previous study [22,23].

Yam bean is a common crop in tropical countries like Indonesia and can be harvested every three months. Yam bean starch has a particularly high amylose content in the range of $30-40 \%$ [8]. This is higher than in tapioca (15\%) [5], corn (28\%) [14], and potato starch (25\%) [24]. Previous research has shown that amylose-rich starch results in bioplastics with superior mechanical properties $[8,25]$.

Therefore, we chose to investigate the properties of a biocomposite manufactured from a low loading of nanofiber cellulose (NFC) from water hyacinth in a TPS matrix from yam beans (YB) in this study. To attempt to produce a bioplastic free from agglomerations and hence even better properties, we used ultrasonic vibration during gelation. To date, there are no published studies on the effect of UVT during the gelation of TPS from YB starch reinforced by water hyacinth NFC. Morphological, mechanical properties and crystallinity index have been analyzed in this study.

\section{Materials and Methods}

\subsection{Materials}

Water hyacinth fiber was obtained from a river in Payakumbuh, Indonesia. The content of cellulose, hemicellulose, and lignin was 43\%, 29\%, and 7\%, respectively. Yam bean (YB) starch (43\% amylose and 57\% amylopectin), glycerol (density: 1.255-1.260 g/mL; Brataco brand), and distilled water were supplied by the Mechanic Metallurgy Laboratory, Andalas University.

\subsection{NFC Preparation}

The water hyacinth NFC preparation was carried out as in [21] with certain modifications in the mechanical treatment. In this study, we used ultrasonic crusher treatment to obtain the NFC. The cellulose suspension was sonicated using ultrasonic cell crusher (SJIA-1200W) at $600 \mathrm{~W}$ for $1 \mathrm{~h}$ after chemical treatment. The temperature of the cellulose suspension was kept below $50{ }^{\circ} \mathrm{C}$.

\subsection{Production of TPS Bionanocomposites}

A mixture of $2 \mathrm{~mL}$ glycerin, $100 \mathrm{~mL}$ distilled water, $10 \mathrm{wt} \%$ YB starch and $1 \mathrm{wt} \%$ NFC was heated on a hot plate in a glass beaker with a magnetic stirrer at $60{ }^{\circ} \mathrm{C}, 500 \mathrm{rpm}$ for $25-30 \mathrm{~min}$ until gelation. During gelation, the bionanocomposite gel was treated in an ultrasonic bath (model number PS-70AL, $40 \mathrm{kHz}$, and $420 \mathrm{~W}$ ). The treatment was conducted at $40 \mathrm{kHz}, 250 \mathrm{~W}$, and $100 \%$ amplitude on four different samples with UVT of $0,15,30$ and $60 \mathrm{~min}$. The water temperature in the bath was kept under $40{ }^{\circ} \mathrm{C}$. The gel was cast in a petri dish (diameter: $15 \mathrm{~cm}$ ) and dried in a Memert UN50 oven at $50{ }^{\circ} \mathrm{C}$ for $20 \mathrm{~h}$. 


\subsection{Characterization}

\subsubsection{Morphology of Untreated and Treated Water Hyacinth Fiber}

The morphology of raw (untreated), bleached, and acid hydrolysis fiber was observed by using the SEM Hitachi $3400 \mathrm{~N}$ instrument. It was observed at $10 \mathrm{kV}$ and room temperature.

\subsubsection{Morphology of NFC Water Hyacinth}

The fiber was studied $1 \mathrm{~h}$ after sonication using TEM (JEOL JEM-1400). The fiber suspension was dripped onto a copper grid coated by carbon film and dried at room temperature. It was observed using TEM at $100 \mathrm{keV}$.

\subsubsection{Fracture Surface Bionanocomposites}

The fracture surface of all bionanocomposite films after the tensile test was observed by SEM VEGA3 TESCAN at room temperature. The operation voltage was HV $10 \mathrm{kV}$. Before characterization, all films were coated with Palladium-Gold (Pd-Au).

\subsubsection{Mechanical Properties}

Tensile tests were performed to determine the mechanical properties of the bionanocomposite films using COM-TEN 95T Series 5K (maximum capacity: 5000 pounds) testing machine. The output of the tensile test was tensile strength, modulus elasticity, and elongation at break. All samples were fabricated in rectangular profile according to American Society for Testing and Materials (ASTM) D882 standard. Length and width overall of sample were 100 and $15 \mathrm{~mm}$, respectively. The gage length was $50 \mathrm{~mm}$. Before testing, all samples tested were conditioned in a desiccator for 2 days (Relative Humidity (RH): 50\%). During testing, the speed and RH were maintained at $5 \mathrm{~mm} / \mathrm{min}$ and $80 \%$, respectively. There were five repeats used for each UVT variation.

Tensile test results were obtained by dividing maximum force by the average cross-sectional area of the sample which was measured at five different points using a micrometer and vernier caliper (accuracy: $0.001 \mathrm{~mm}$ ) for thickness and width.

\subsubsection{Crystallinity Index Calculation}

A PANalytical X'pert PRO instrument was used to perform the XRD of all samples tested. The peak intensity was recorded at $\left(2 \theta=10-80^{\circ}\right)(\lambda=0.154 \mathrm{~nm})$ using $40 \mathrm{kV}$ and $35 \mathrm{~mA}$. Crystallinity index $(C I)$ of the NFC water hyacinth samples was calculated by the Segal's Equation (1) [26]:

$$
C I(\%)=\frac{I_{002}-I_{a m}}{I_{002}} \times 100
$$

where, $I_{002}$ was maximum crystalline peak intensity at $\left(2 \theta=22.6^{\circ}\right)$ and $I_{a m}$ the amorphous diffraction intensity at $\left(2 \theta=18^{\circ}\right)$. Meanwhile, the $C I$ of all bionanocomposites was determined by Hulleman's method [27].

\section{Results and Discussion}

\subsection{Morphology of Untreated and Treated Water Hyacinth Fiber}

Figure 1 presents the appearance of raw water hyacinth, bleaching fiber, acid hydrolysis fiber, and water hyacinth NFC processed by ultrasonic cell crusher for $1 \mathrm{~h}$. It can be seen that; raw fiber forms several fiber bundles and has a smooth surface due to the presence of cementing material such as waxes and oils (Figure 1a) [28]. After bleaching, the water hyacinth fiber disintegrated due to the hydrolyzation of hemicellulose and partial removal of the lignin [29]. Acid hydrolysis of the fiber then depolymerized it by breaking up the cellulose chains [18,29]. The resulting fibers have diameters of 
1-10 micron. After $1 \mathrm{~h}$ sonication (Figure $1 \mathrm{~d}$ ), fibers took the form of short fibrils with average diameter and length of 10-20 nm and 90-250 nm, respectively as has been observed in previous reports [30,31].

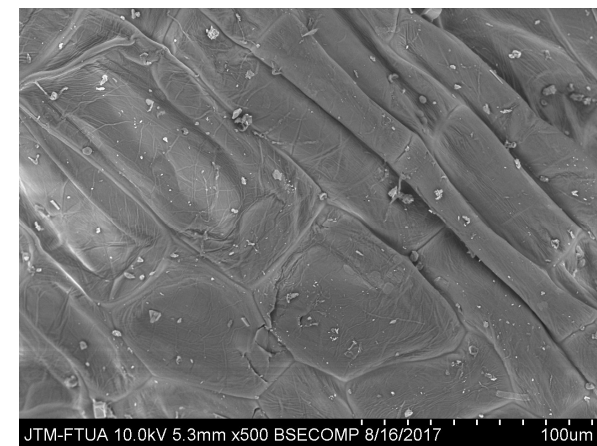

(a)

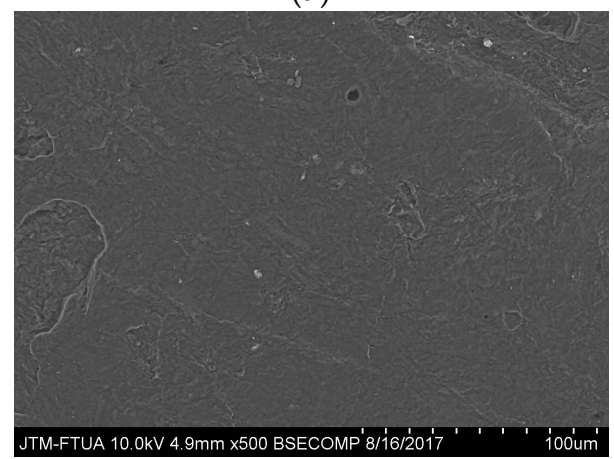

(c)

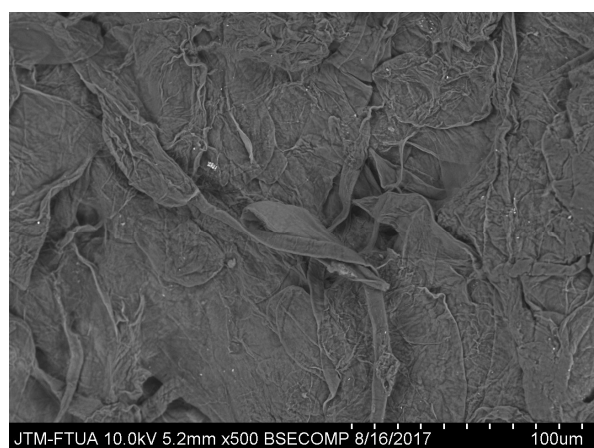

(b)

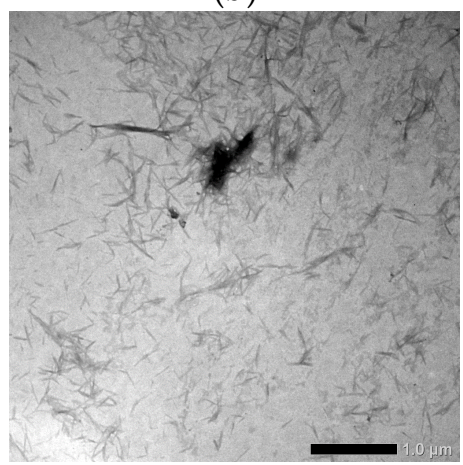

(d)

Figure 1. SEM images of morphological: (a) raw water hyacinth; (b) bleached fiber; (c) acid hydrolysis fiber; (d) TEM images of nanofiber cellulose (NFC) water hyacinth after sonication for $1 \mathrm{~h}$.

\subsection{Fractured Surface of Bionanocomposites}

Figure 2 displays SEM imaging of TPS and all fractured bionanocomposite samples after the tensile test. Figure $2 \mathrm{a}$ shows the fracture surface of the TPS film. It looks to be a smooth surface and there is no aggregation due to good interaction between starch and glycerol during the fabrication process [32]. The addition of NFC $1 \mathrm{wt} \%$ in TPS (untreated) is displayed by Figure 2b,c. As can be seen, there is porosity formation at several spots. The NFC also seems undistributed in starch matrix. This is due to a bad interaction between starch and NFC during fabrication [33]. This would appear to be a cause of the low tensile strength. For 15 min UVT (Figure 2d), the sample NFC agglomerates at one spot due to bad dispersion in the matrix [33,34]. A similar phenomenon was also reported by a previous report $[5,6]$. After 30 and $60 \mathrm{~min}$ UVT, the samples display good nanocellulose dispersion throughout the matrix and compact structure with no porosity or agglomeration formation (Figure 2e,f). The kinetic energy from the ultrasonic bath disperses the agglomerated fiber well resulting in a good distribution throughout the matrix leading to good mechanical properties $[6,20,35]$. 


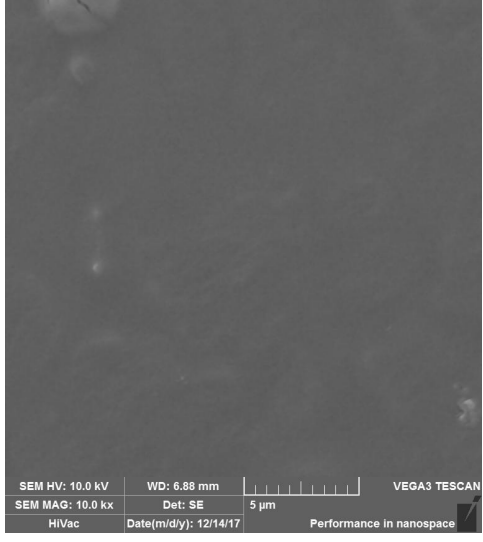

(a)

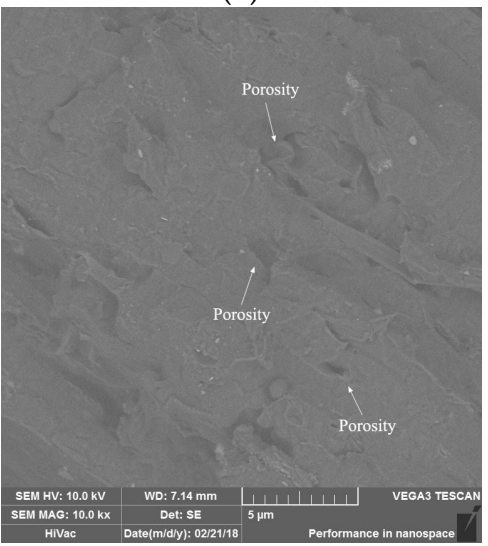

(c)

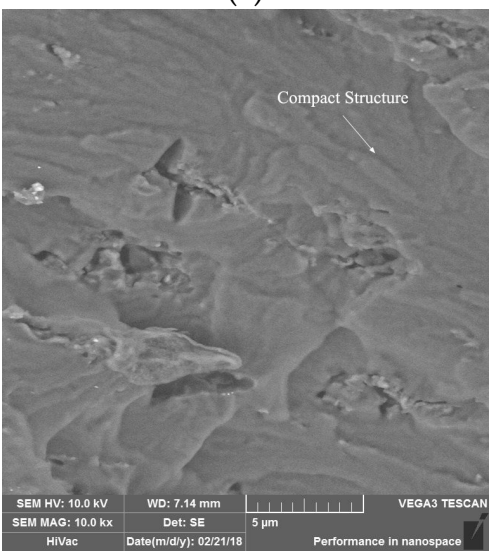

(e)

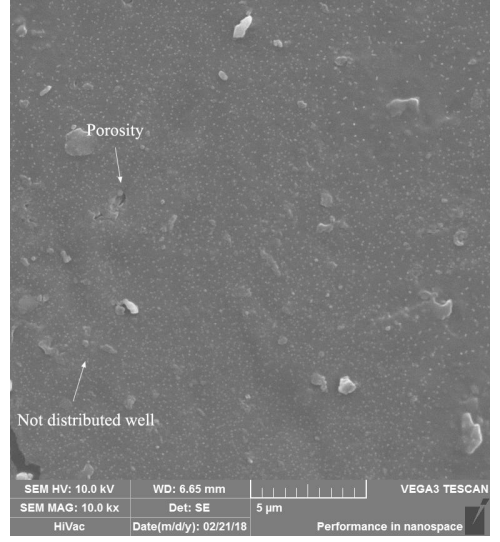

(b)

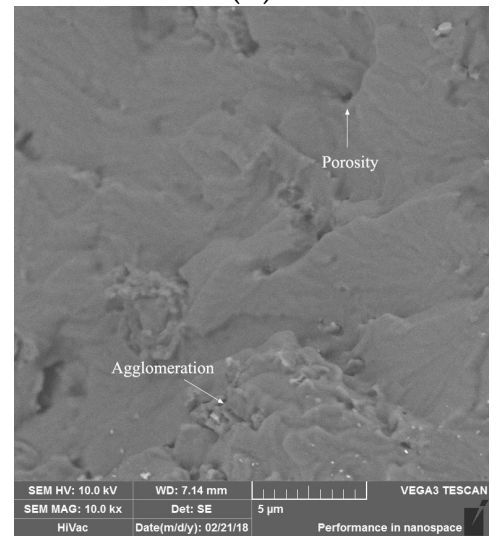

(d)

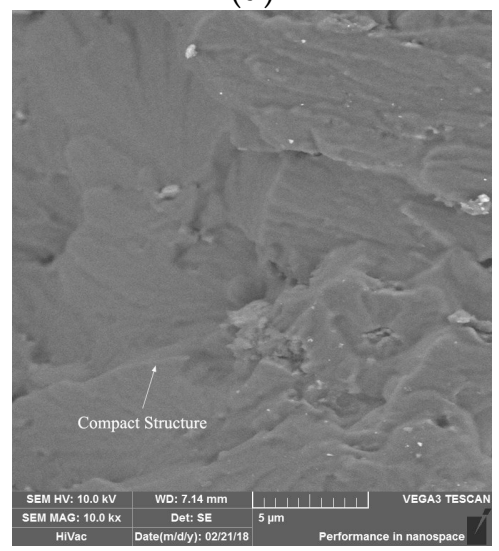

(f)

Figure 2. SEM images of fractured surface: (a) pure thermoplastic starch (TPS) film; (b) TPS reinforced $1 \mathrm{wt} \%$; bionanocomposites with different UVT: (c) 0 min (untreated); (d) $15 \mathrm{~min}$; (e) $30 \mathrm{~min}$; and (f) $60 \mathrm{~min}$.

\subsection{Mechanical Properties}

The effect of UVT on mechanical properties of bionanocomposite is displayed in Figure 3. The TS and ME increased significantly with longer UVT. The 0 min UVT (untreated) bionanocomposite (Figure 3a) had a TS of $4 \mathrm{MPa}$. This result was lower than in the treated bionanocomposite due to porosities formation and poorly distributed fiber in the starch matrix (see Figure 2b,c). After 15 min UVT, the TS was increased by $45 \%$. Longer UVT for 30 and $60 \mathrm{~min}$ increased TS to $82 \%$ and $185 \%$, respectively. 


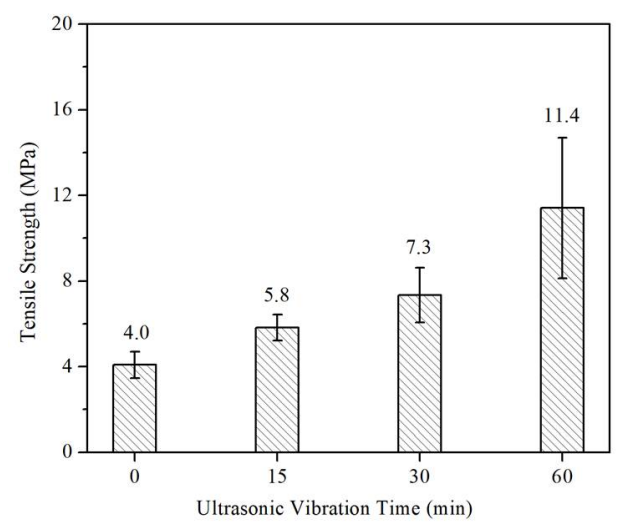

(a)

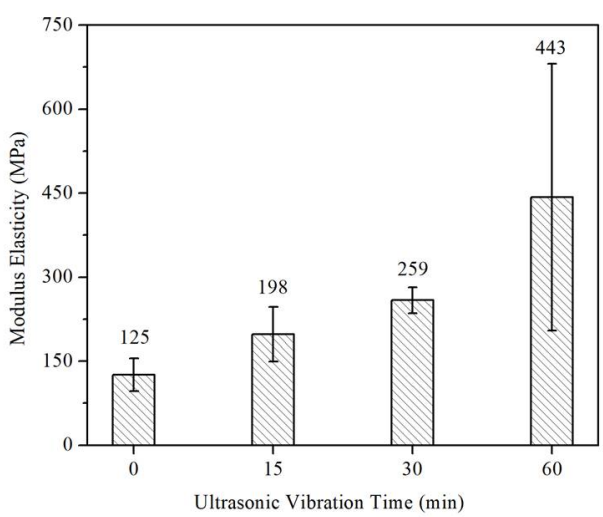

(b)

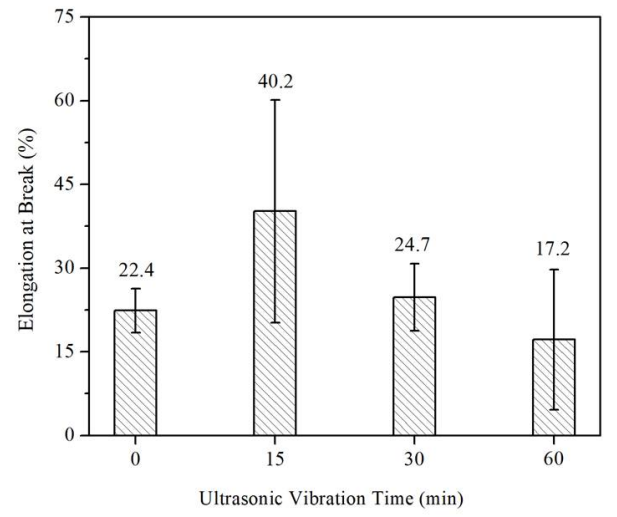

(c)

Figure 3. Effect ultrasonic vibration time (UVT) on: (a) Tensile Strength (TS); (b) Modulus Elasticity (ME); and (c) Elongation of break (EB) of bionanocomposite samples.

Longer UVT also increased ME and decreased EB of the bionanocomposite (Figure 3b,c). The ME after 30 and 60 min UVT was increased by $107 \%$ and $254 \%$ compared to the untreated bionanocomposite due to good adhesion bonding between nanofiber cellulose and starch matrix [35,36]. UVT also compacts the structure [5]. This fact was supported by SEM observation of the fracture surface (Figure 2e,f). Previous research has reported that ultrasonic treatment reduces the porosities, improves the dispersion of fiber in matrix, the adhesion between matrix and fiber which results in high tensile strength [6]. The treated bionanocomposite in this research had a TS two times higher than water hyacinth microfiber reinforced TPS in a previous study [5], suggesting that nano-sized fibers and UVT treatment significantly improves the properties of bionanocomposites.

\subsection{Crystallinity Index Analysis}

The XRD formation of NFC water hyacinth, pure TPS, and all bionanocomposites is displayed in Figure 4. It can be seen that NFC shows two main peaks which indicates the cellulose type I. This is caused by interaction between hydroxyl groups of cellulose [21]. The NFC water hyacinth had a CI of about $80 \%$. This value was higher than other sources such as water hyacinth processed by high shear homogenization [21], cassava bagasse cellulose nanofibrils [30], and garlic stalks [32].

Pure TPS film had two peaks around $2 \theta=15-20^{\circ}$. The peak at $2 \theta$ around $17^{\circ}$ indicates the amylopectin recrystallization (B-type crystallization). Meanwhile, the peak intensity at $2 \theta$ around $19.8^{\circ}$ indicates VH-type recrystallization of amylose during cooling after fabrication because of the presence of glycerol, isopropanol, and lysophospholipids content [30]. According to the previous report, the calculation of CI used the Hulleman's method [27]. The CI of pure TPS film was $23 \%$. 
The addition of NFC in TPS matrix in a UVT treatment makes some changes in peak intensity. It can be seen that with longer UVT, peak intensity increases. This is probably due to a number of factors such as more complete gelation of starch during fabrication, homogeneity of the distribution of fiber in the starch matrix, and good adhesion bonding between fiber and matrix [6,37]. According to a previous report, amylose recrystallizes during gelation which changes the matrix structure and affects XRD peak intensity [6]. In addition, reduction of the agglomeration of fiber in the starch matrix will significantly influence the visible peak intensity $[5,6]$.

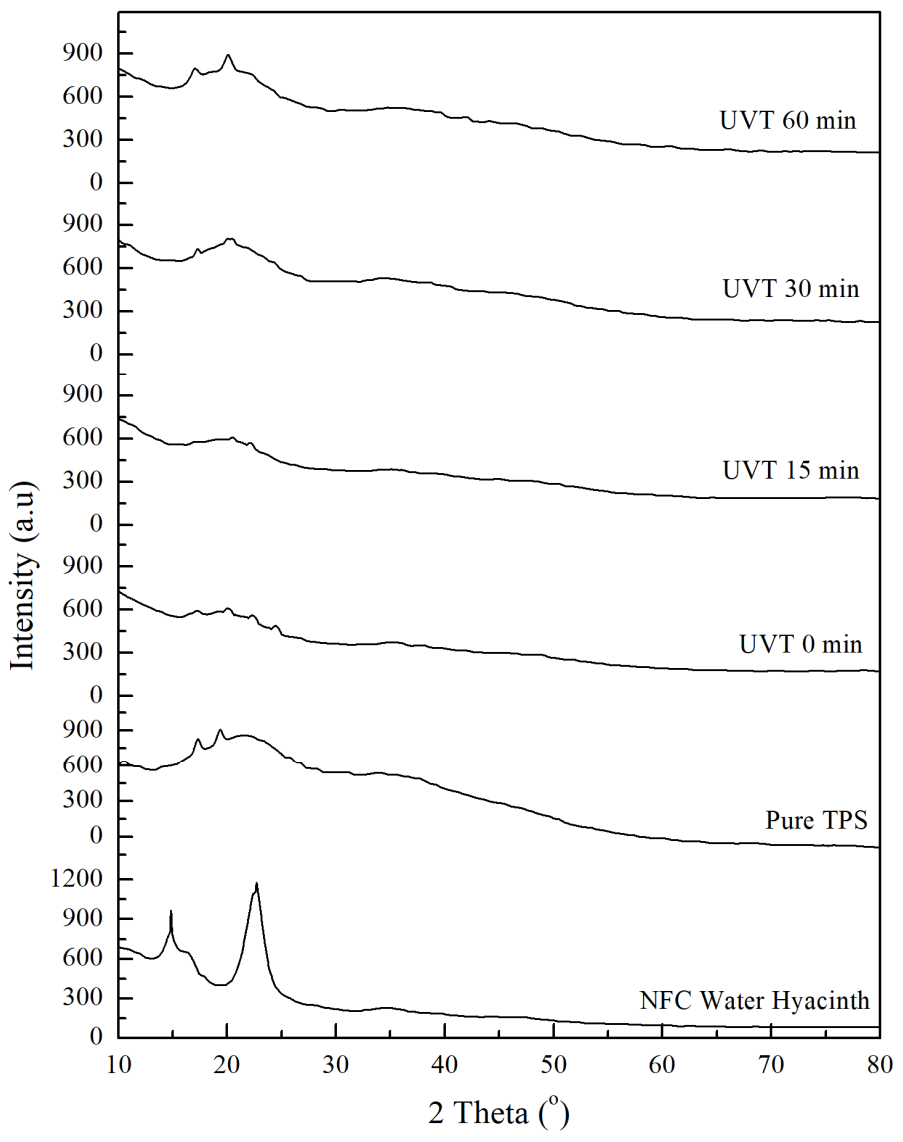

Figure 4. XRD pattern of all samples tested.

CI of TPS bionanocomposite after UVT of $0,15,30$, and 60 min was $7,8,18$, and $35 \%$, respectively. Longer UVT leads to increasing CI. Despite the lower fiber loading, the UVT treated CI are comparable to $\mathrm{CI}$ of non-vibrated bionanocomposites from several other sources [24,30] and are significantly higher than sugarcane bagasse nanofiber $(20 \mathrm{wt} \%)$ reinforced potato starch $(24.4 \% \mathrm{CI})$ [24]. High CI corresponds to good mechanical properties (see Figure 3a).

\section{Conclusions}

UVT of yam bean TPS reinforced with a $1 \mathrm{wt} \%$ loading of water hyacinth NFC improved its mechanical properties. A $1 \mathrm{wt} \%$ loading of water hyacinth NFC reinforcement improved the mechanical properties of UVT of yam bean TPS. The maximum value tensile strength obtained was $11.4 \mathrm{MPa}$ after $60 \mathrm{~min}$ UVT. The highest crystallinity index was 35\% after $60 \mathrm{~min}$ UVT. Values obtained were in the same range as non-sonicated biocomposites from similar materials but with much higher nanofiber loadings. The improvement of mechanical properties and crystallinity index due to ultrasonication could enable a significant reduction of the amount of filler loading required in a matrix. 
Author Contributions: M.A. conducted the experiments, wrote the paper and analyzed the data; H.A. as the supervisor of this research provides the addition of in-depth addition analyzed the data, improved the paper quality; A.K. and A.P. as the co-promotor provide additional explanation of characterization, M.M. and F.H. gave their energy and time to help the fabrication of bionanocomposite samples during experiment.

Acknowledgments: This research was funded by Directorate General of Higher Education Ministry of National Education (KEMENRISTEK DIKTI), Indonesia, with project name The Research of Master Program Leading to Doctoral Degree for Excellent Students (PMDSU Batch-2) in the year of 2018. We also thank Fay Farley for her proofreading.

Conflicts of Interest: The authors declare no conflict of interest.

\section{References}

1. Ahmed, T.; Shahid, M.; Azeem, F.; Rasul, I.; Shah, A.A.; Noman, M.; Hameed, A.; Manzoor, N.; Manzoor, I.; Muhammad, S. Biodegradation of plastics: Current scenario and future prospects for environmental safety. Environ. Sci. Pollut. Res. 2018, 25, 1-12. [CrossRef] [PubMed]

2. Shit, S.C.; Shah, P.M. Edible polymers: Challenges and opportunities. J. Polym. 2014, 2014, 427259. [CrossRef]

3. Kaewtatip, K.; Thongmee, J. Studies on the structure and properties of thermoplastic starch/luffa fiber composites. Mater. Des. 2012, 40, 314-318. [CrossRef]

4. Karimi, S.; Abdulkhani, A.; Tahir, P.M.; Dufresne, A. Effect of cellulosic fiber scale on linear and non-linear mechanical performance of starch-based composites. Int. J. Biol. Macromol. 2016, 91, 1040-1044. [CrossRef] [PubMed]

5. Asrofi, M.; Abral, H.; Putra, Y.K.; Sapuan, S.M.; Kim, H.J. Effect of duration of sonication during gelatinization on properties of tapioca starch water hyacinth fiber biocomposite. Int. J. Biol. Macromol. 2018, 108, 167-176. [CrossRef] [PubMed]

6. Abral, H.; Putra, G.J.; Asrofi, M.; Park, J.W.; Kim, H.J. Effect of vibration duration of high ultrasound applied to bio-composite while gelatinized on its properties. Ultrason. Sonochem. 2018, 40, 697-702. [CrossRef] [PubMed]

7. Mohanty, A.K.; Misra, M.; Drzal, L.T. Surface modifications of natural fibres and peformance of the resulting biocomposite: An overview. Compos. Interfaces 2001, 8, 313-343. [CrossRef]

8. Mali, S.; Grossmann, E.M.V.; Garcia, M.A.; Martino, M.N.; Zaritzky, N.E. Mechanical and thermal properties of yam starch films. Food Hydrocoll. 2005, 19, 157-164. [CrossRef]

9. Abral, H.; Lawrensius, V.; Handayani, D.; Sugiarti, E. Preparation of nano-sized particles from bacterial cellulose using ultrasonication and their characterization. Carbohydr. Polym. 2018, 191, 161-167. [CrossRef] [PubMed]

10. Lim, C.T. Nanofiber technology: Current status and emerging developments. Prog. Polym. Sci. 2017, 70, $1-17$.

11. Asrofi, M.; Abral, H.; Kasim, A.; Pratoto, A. Characterization of the microfibrillated cellulose from water hyacinth pulp after alkali treatment and wet blending. IOP Conf. Ser. Mater. Sci. Eng. 2017, 204, 012018. [CrossRef]

12. Wahono, S.; Irwan, A.; Syafri, E.; Asrofi, M. Preparation and characterization of ramie cellulose nanofibers /CaCO3 unsaturated polyester resin composites. ARPN J. Eng. Appl. Sci. 2018, 13, 746-751.

13. Syafri, E.; Kasim, A.; Abral, H.; Asben, A. Effect of precipitated calcium carbonate on physical, mechanical and thermal properties of cassava starch bioplastic composites. Int. J. Adv. Sci. Eng. Inf. Technol. 2017, 7, 1950-1956. [CrossRef]

14. Fabra, M.J.; Martínez-Sanz, M.; Gómez-Mascaraque, L.G.; Gavara, R.; López-Rubio, A. Structural and physicochemical characterization of thermoplastic corn starch films containing microalgae. Carbohydr. Polym. 2018, 186, 184-191. [CrossRef] [PubMed]

15. Salaberria, A.M.; Labidi, J.; Fernandes, S.C.M. Chitin nanocrystals and nanofibers as nano-sized fillers into thermoplastic starch-based biocomposites processed by melt-mixing. Chem. Eng. J. 2014, 256, 356-364. [CrossRef]

16. Abdul Khalil, H.P.S.; Tye, Y.Y.; Saurabh, C.K.; Leh, C.P.; Lai, T.K.; Chong, E.W.N.; Nurul Fazita, M.R.; Mohd Hafiidz, J.; Banerjee, A.; Syakir, M.I. Biodegradable polymer films from seaweed polysaccharides: A review on cellulose as a reinforcement material. Express Polym. Lett. 2017, 11, 244-265. [CrossRef] 
17. De Campos, A.; De Sena Neto, A.R.; Rondrigues, V.B.; Luchesi, B.R.; Moreira, F.K.V.; Correa, A.C.; Mattoso, L.H.C.; Marconcini, J.M. Bionanocomposites produced from cassava starch and oil palm mesocarp cellulose nanowhiskers. Carbohydr. Polym. 2017, 175, 330-336. [CrossRef] [PubMed]

18. Julie Chandra, C.S.; George, N.; Narayanankutty, S.K. Isolation and characterization of cellulose nanofibrils from arecanut husk fibre. Carbohydr. Polym. 2016, 142, 158-166.

19. Abral, H.; Anugrah, A.S.; Hafizulhaq, F.; Handayani, D.; Sugiarti, E.; Muslimin, A.N. Effect of nanofibers fraction on properties of the starch based biocomposite prepared in various ultrasonic powers. Int. J. Biol. Macromol. 2018, 116, 1214-1221. [CrossRef] [PubMed]

20. Cheng, W.; Chen, J.; Liu, D.; Ye, X.; Ke, F. Impact of ultrasonic treatment on properties of starch film-forming dispersion and the resulting films. Carbohydr. Polym. 2010, 81, 707-711. [CrossRef]

21. Asrofi, M.; Abral, H.; Kasim, A.; Pratoto, A. XRD and FTIR studies of nanocrystalline cellulose from water hyacinth (Eichornia crassipes) fiber. J. Metastable Nanocryst. Mater. 2017, 29, 9-16. [CrossRef]

22. Abral, H.; Dalimunthe, M.H.; Hartono, J.; Efendi, R.P.; Asrofi, M.; Sugiarti, E.; Sapuan, S.M.; Park, J.W.; Kim, H.J. Characterization of tapioca starch biopolymer composites reinforced with micro scale water hyacinth fibers. Starch-Stärke 2018. [CrossRef]

23. Komuraiah, A.; Kumar, N.S.; Prasad, B.D. Chemical composition of natural fibers and its influence on their mechanical properties. Mech. Compos. Mater. 2014, 50, 359-376. [CrossRef]

24. Gilfillan, W.N.; Moghaddam, L.; Doherty, W.O.S. Preparation and characterization of composites from starch with sugarcane bagasse nanofibres. Cellulose 2014, 21, 2695-2712. [CrossRef]

25. Tharanathan, R.N. Biodegradable films and composite coatings: Past, present and future. Trends Food Sci. Technol. 2003, 14, 71-78. [CrossRef]

26. Segal, L.; Creely, J.J.; Martin, A.E.; Conrad, C.M. An empirical method for estimating the degree of crystallinity of native cellulose using the X-ray Diffractometer. Text. Res. J. 1959, 29, 786-794. [CrossRef]

27. Hulleman, S.H.D.; Kalisvaart, M.G.; Janssen, F.H.P.; Feil, H.; Vliegenthart, J.F.G. Origins of B-type crystallinity in glycerol-plasticised, compression-moulded potato starches. Carbohydr. Polym. 1999, 39, 351-360. [CrossRef]

28. Abraham, E.; Deepa, B.; Pothan, L.A.; Jacob, M.; Thomas, S.; Cvelbar, U.; Anandjiwala, R. Extraction of nanocellulose fibrils from lignocellulosic fibres: A novel approach. Carbohydr. Polym. 2011, 86, 1468-1475. [CrossRef]

29. Cherian, B.M.; Leao, A.L.; De Souza, S.F.; Thomas, S.; Photan, L.A.; Kottaisamy, M. Isolation of nanocellulose from pineapple leaf fibres by steam explosion. Carbohydr. Polym. 2010, 81, 720-725. [CrossRef]

30. Teixeira, E.D.M.; Pasquini, D.; Curvelo, A.A.S.; Corradini, E.; Belgacem, M.N.; Dufresne, A. Cassava bagasse cellulose nanofibrils reinforced thermoplastic cassava starch. Carbohydr. Polym. 2009, 78, 422-431. [CrossRef]

31. Mahardika, M.; Abral, H.; Kasim, A.; Arief, S.; Asrofi, M. Production of nanocellulose from pineapple leaf fibers via high-shear homogenization and ultrasonication. Fibers 2018, 6, 28. [CrossRef]

32. Agustin, M.B.; Ahmmad, B.; De Leon, E.R.P.; Buenaobra, J.L.; Salazar, J.R.; Hirose, F. Starch-based biocomposite films reinforced with cellulose nanocrystals from garlic stalks. Polym. Compos. 2013, 34, 1325-1332. [CrossRef]

33. Kargarzadeh, H.; Johar, N.; Ahmad, I. Starch biocomposite film reinforced by multiscale rice husk fiber. Compos. Sci. Technol. 2017, 151, 147-155. [CrossRef]

34. Hermansyah, H.; Carissa, R.; Faiz, M.B.; Deni, P. Food grade bioplastic based on corn starch with banana pseudostem fibre/bacterial cellulose hybrid filler. Adv. Mater. Res. 2014, 997, 158-168. [CrossRef]

35. Carmona-García, R.; Bello-Pérez, L.A.; Aguirre-Cruz, A.; Aparicio-Saguilán, A.; Hernández-Torres, J.; Alvarez-Ramirez, J. Effect of ultrasonic treatment on the morphological, physicochemical, functional, and rheological properties of starches with different granule size. Starch-Stärke 2016, 68, 972-979. [CrossRef]

36. Nascimento, P.; Marim, R.; Carvalho, G.; Mali, S. Nanocellulose produced from rice hulls and its effect on the properties of biodegradable starch films. Mater. Res. 2016, 19, 167-174. [CrossRef]

37. Monroy, Y.; Rivero, S.; García, M.A. Microstructural and techno-functional properties of cassava starch modified by ultrasound. Ultrason. Sonochem. 2018, 42, 795-804. [CrossRef] [PubMed]

(C) 2018 by the authors. Licensee MDPI, Basel, Switzerland. This article is an open access article distributed under the terms and conditions of the Creative Commons Attribution (CC BY) license (http:/ / creativecommons.org/licenses/by/4.0/). 